Marquette University

e-Publications@Marquette

\title{
The Impact of Metal Pipe Materials, Corrosion Products, and Corrosion Inhibitors on Antibiotic Resistance in Drinking Water Distribution Systems
}

Lee Kimbell

Yin Wang

Patrick J. McNamara

Follow this and additional works at: https://epublications.marquette.edu/civengin_fac

Part of the Civil Engineering Commons 
Marquette University

e-Publications@Marquette

\section{Civil, Construction and Environmental Engineering Faculty Research and Publications/College of Engineering}

This paper is NOT THE PUBLISHED VERSION.

Access the published version via the link in the citation below.

Applied Microbiology and Biotechnology, Vol. 104, No. 18 (September 2020): 7673-7688. DOI. This article is (C Springer-Verlag GmbH Germany, part of Springer Nature and permission has been granted for this version to appear in e-Publications@Marquette. Springer-Verlag GmbH Germany, does not grant permission for this article to be further copied/distributed or hosted elsewhere without the express permission from Springer-Verlag GmbH Germany,.

\section{The Impact of Metal Pipe Materials, Corrosion Products, and Corrosion Inhibitors on Antibiotic Resistance in Drinking Water Distribution Systems}

Lee K. Kimbell

Department of Civil, Construction and Environmental Engineering, Marquette University, Milwaukee, WI

Yin Wang

Department of Civil and Environmental Engineering, University of Wisconsin - Milwaukee, Milwaukee, WI

Patrick J. McNamara

Department of Civil, Construction and Environmental Engineering, Marquette University, Milwaukee, WI 


\section{Abstract}

Drinking water distribution systems (DWDS) are unique engineering environments that are important routes for the acquisition and dissemination of antibiotic resistance. Antibiotic-resistant bacteria (ARB) and antibiotic resistance genes (ARGs) in drinking water pose risks to human and environmental health. Metals are known stressors that can select for antibiotic resistance. The objective of this review was to assess the state of knowledge regarding the impact of metal pipe materials, corrosion products, and corrosion inhibitors on the prevalence of antibiotic resistance in DWDS. ARGs and mobile genetic elements (MGEs) have been detected in full-scale DWDS in concentrations ranging from $10^{1}$ to $10^{10}$ copies/L. Metal pipe materials can select for bacteria harboring ARGs and metal resistance genes (MRGs) through co-selection processes. Corrosion products that develop in metal drinking water pipes ( $\mathrm{Cu}, \mathrm{Fe}$, and $\mathrm{Pb}$ oxides) may also stimulate antibiotic resistance selection during distribution. Different corrosion inhibitor regimes (phosphates, sodium silicates) may also have impacts on microbial communities and the abundance of resistance genes in DWDS. Research is needed to quantify how engineering decisions related to drinking water infrastructure and corrosion inhibitor practices impact the abundance and distribution of ARG, MRGs, and MGEs in potable water systems.

\section{Key points}

- Lack of quantitative measurements of antibiotic and metal resistance genes in drinking water distribution systems.

- Pipe materials and corrosion products that develop in pipe scales may impact antibiotic resistance.

- Corrosion inhibitors with zinc or phosphate could alter antibiotic resistance.

- Management decisions should consider antibiotic resistance ramifications.

\section{Keywords}

Antimicrobial resistance, ARG, Microbiome, Public health, Biofilm

\section{Introduction}

Antibiotic resistance is considered a major global threat in the $21^{\text {st }}$ century, and a return to a pre-antibiotic era is predicted without serious or immediate attention (WHO [167]). Antibiotic-resistant bacteria (ARB) and antibiotic resistance genes (ARGs) occur naturally but are selected for and enriched by exposure to antibiotics (Song et al. [152]), antimicrobials (Carey and McNamara [22]; Carey et al. [23]; Hartmann et al. [60]; Harrison et al. [59]), disinfectants (Chapman [25]; Zhang et al. [183]), and metals (Seiler and Berendonk [148]; Zhang et al. [182]) in natural and engineered environments. ARB and ARGs have been detected in a variety of environments including soils (Knapp et al. [73]), lakes (Di Cesare et al. [33]), groundwater (Mackie et al. [100]; Koike et al. [75]), aquaculture (Seiler and Berendonk [148]), rivers (Pruden et al. [133]; Pruden et al. [132]; Kappell et al. [68]), treated wastewater effluent (Auerbach et al. [8]; LaPara et al. [78]; Mao et al. [102]; Di Cesare et al. [32]; Guo et al. [51]; Kappell et al. [70]; Cacace et al. [20]), biosolids (Ma et al. [99]; Munir and Xagoraraki [108]; Kimbell et al. [71]), drinking water treatment plants (Xi et al. [170]; Lin et al. [87]; Oh et al. [113]), drinking water distribution systems (DWDS) (Xi et al. [170]; Xu et al. [174]; Garner et al. [45]), and tap drinking water (Xi et al. [170]; Bergeron et al. [14]). Natural and engineered environments are composed of complex dynamics driven by microbial ecological processes that ultimately determine the level of prevailing antibiotic resistance (Pruden et al. [131]). ARB and ARGs can be transferred between environments via exposure routes through air, water, soil, wastewater and industrial effluent discharges, bacteria carrying ARGs on meat or produce, and application of biosolid-derived soil amendments (Vikesland et al. [161]; Pruden et al. [131]). Environmental hotspots that could directly convey ARB and ARGs to people, such as DWDS, are of primary interest because management decisions could potentially reduce public health risks. 
Over 100 different ARGs were detected in drinking water from two drinking water treatment plants in China with total ARG concentrations ranging from $10^{5}$ to $10^{10}$ copies/L (Xu et al. [174]). Multiple studies correlated the presence of ARGs with mobile genetic elements (MGEs), suggesting that horizontal gene transfer could occur inside the DWDS (Ciric et al. [27]; Xu et al. [174]). In general, ARGs can be transferred vertically through microbial growth or acquired by horizontal gene transfer, which occurs through the uptake of free DNA (transformation), plasmid-mediated transfer (conjugation), and phage-mediated transfer (transduction) (Van Hoek et al. [160]). Horizontal gene transfer is a major mechanism for sharing ARGs between microorganisms and has been documented between pathogens, non-pathogens, and distantly related microbes, such as grampositive and gram-negative bacteria (Levy et al. [85]; Courvalin [28]; Pruden et al. [133]). Horizontal gene transfer of ARGs is of particular concern for human health if pathogens acquire resistance (Wingender and Flemming [168]; Wang et al. [164]). Additionally, metal resistance is a common phenotype in many microorganisms, and metal resistance genes (MRGs) are present in genomes isolated from numerous different environments including humans, animals, hydrothermal vents, and ocean microplastics (Pal et al. [115]; Yang et al. [176]). Metal resistance often occurs with antibiotic resistance (Baker-Austin et al. [9]). Stagnant conditions caused by intermittent water demand, which are common in urban areas, may also promote the growth of pathogens and other microorganisms potentially harboring ARGs and MRGs in DWDS (Lautenschlager et al. [79]; Proctor and Hammes [130]; Zlatanović et al. [188]; Bédard et al. [13]; Ling et al. [88]). Additionally, locations within DWDS that support higher densities of microorganisms (e.g., biofilms, tubercles, and loose deposits) may aid in the persistence of antibiotic resistance in DWDS (Hallam et al. [54]). The overall growth of microorganisms and microbial ecology in DWDS is influenced by several distribution system characteristics and may have implications on the types and abundance of resistance genes in DWDS. Even though metals are known to select for antibiotic resistance, and they are present in DWDS due to corrosion of metal pipes and addition of corrosion inhibitors, research gaps persist around the impact of metals on antibiotic resistance in DWDS.

Previous analysis of microbial ecology in DWDS has been accomplished primarily through next-generation sequencing (NGS) technologies including 16S rRNA gene amplicon sequencing and DNA-based metagenomic analysis (Berry et al. [15]; Pinto et al. [125]; Douterelo et al. [35]; Ma et al. [97]). Many of these studies have investigated the drinking water microbiome during various stages of drinking water treatment and distribution, which can be influenced by many factors including spatial and temporal variations (Pinto et al. [124]; Prest et al. [128]; Potgieter et al. [127]), geography (Proctor and Hammes [130]), treatment processes (Ma et al. [98]; Oh et al. [113]), and distribution system characteristics (Sanganyado and Gwenzi [142]). Laboratory-scale studies have observed relationships between several distribution system parameters and the occurrence of opportunistic pathogens and microbial ecology in simulated DWDS including disinfectants (Shen et al. [150]; Zhang et al. [177]), water age (Wang et al. [165]; Wang et al. [164]), water temperature (Proctor et al. [129]), and pipe materials (Wang et al. [165]; Wang et al. [164]; Proctor et al. [129]). ARG profiles are impacted by the microbial communities in a given environment, and many of these previously studied parameters likely have impacts on antibiotic resistance in drinking water systems but have yet to be investigated. Additionally, few studies have utilized quantitative molecular tools to quantify the abundance of clinically relevant ARGs or MGEs in different phases (planktonic, biofilm, particle-associated, loose deposits) of full-scale DWDS (Garner et al. [45]).

In this review, existing information on the impacts of metal pipe materials, corrosion inhibitors, and corrosion products on the prevalence of antibiotic resistance in DWDS is critically reviewed with the goal of consolidating information to help develop more effective monitoring and mitigation strategies along with recommended future research directions. As older DWDS get upgraded, there is an urgent need for improving our understanding of engineering management decisions such as pipe material selection on the dissemination of antibiotic resistance in DWDS. Here, we provide information regarding the antimicrobial activity of metals and potential mechanisms of antibiotic resistance selection in DWDS with specific emphasis on corrosion products and corrosion inhibitors. This review also summarizes existing information available regarding the abundance of 
ARGs, MRGs, and MGEs in DWDS. Additionally, recommendations are provided for future research directions with a focus on improving mitigation strategies for antibiotic resistance in DWDS.

\section{Quantification of Resistance Genes in Full-Scale Drinking Water Systems}

Understanding the sources and mechanisms of antibiotic resistance dissemination in drinking water networks is critical for mitigating risks to public health. Previous studies have highlighted that several factors related to drinking water treatment (Sharma et al. [149]; Sanganyado and Gwenzi [142]) and distribution system construction and operation can influence the abundance of bacteria in drinking water and biofilms (Douterelo et al. [35]; Sun et al. [155]; Douterelo et al. [37]). After finished drinking water enters the distribution system, it can spend hours to days inside pipes prior to reaching consumer taps, which can alter the chemical and microbiological quality of the water (Ji et al. [65]). Corrosion inhibitors, pH, dissolved inorganic carbon, disinfectant type/concentration, and other chemicals used during drinking water treatment (e.g., coagulants) may impact the presence and distribution of ARB and ARGs in DWDS (Liu et al. [91]; Zhang et al. [183]). A previous laboratory-scale study documented increased transfer of ARGs following exposure to disinfectants (free chlorine, chloramine, and hydrogen peroxide) and suggested that mechanisms including intracellular reactive oxygen species formation, SOS response, increased cell permeability, and altered expression of conjugation-relevant genes were responsible for horizontal gene transfer (Zhang et al. [183]). Additionally, Kappell et al. [69] observed increased selection for ARB and ARGs including sul1, qacH, and int/1 in drinking water microcosms treated with zinc-containing corrosion inhibitors compared to controls. This study reported that low concentrations of metals such as zinc in drinking water can lead to positive selection of bacteria able to assimilate metals, rather than negatively selecting against bacteria without metal resistance (Kappell et al. [69]). Although these studies have provided some insight into the potential mechanisms of antibiotic resistance selection under controlled laboratory conditions, there is a lack of data available regarding the presence of clinically relevant ARGs, MRGs, and MGEs commonly linked to horizontal gene transfer processes in full-scale DWDS. ARGs including beta-lactam resistance genes, sul1, and MGEs such as int/1 have previously been identified as potential indicators for the overall abundance of resistance genes in different environments (WHO [167]; Gillings et al. [49]; Ma et al. [96]). MRGs such as arsB, copA, czcD, and zntA confer resistance to metals, and may be co-selected for by bacterial exposure to antibiotics, disinfectants, and other contaminants (Pal et al. [115]). Furthermore, a previous study documented the co-occurrence of MRGs and ARGs on plasmids in clinically relevant genera including Escherichia, Staphylococcus, Salmonella, Klebsiella, Pseudomonas, and Mycobacterium (Pal et al. [116]). However, no studies known to the authors have documented MRGs in samples from full-scale DWDS using quantitative molecular techniques, i.e., techniques that generate copy numbers on a per $L, g$, or surface area basis. Few studies have employed quantitative techniques to quantify ARGs in full-scale DWDS (summarized in Table 1). 
Table 1. ARGs quantified in full-scale drinking water distribution systems (DWDS)

\begin{tabular}{|c|c|c|c|c|c|c|c|c|c|}
\hline Reference & $\begin{array}{l}\text { Garner et } \\
\text { al } 2018\end{array}$ & & & & $\begin{array}{l}\text { Hao et } \\
\text { al. } 2019\end{array}$ & $\begin{array}{l}\text { Rocha et } \\
\text { al. } 2019\end{array}$ & \begin{tabular}{|l|} 
Su et \\
al. 2018
\end{tabular} & $\begin{array}{l}\text { Xi et } \\
\text { al. } 2009\end{array}$ & $\begin{array}{l}\text { Zhang et } \\
\text { al. } 2020\end{array}$ \\
\hline Sample type & Tap water & Tap water & Biofilms & Biofilms & $\begin{array}{l}\text { Tap } \\
\text { water }\end{array}$ & Tap water & Tap water & Tap water & Tap water \\
\hline $\begin{array}{l}\text { Method of } \\
\text { quantification }\end{array}$ & qPCR & qPCR & qPCR & qPCR & qPCR & qPCR & qPCR & qPCR & qPCR \\
\hline Units & Copies/mL & Copies/mL & Copies/swab & Copies/swab & Copies/L & Copies/mL & Copies/L & $\begin{array}{l}\text { Copies/100 } \\
\mathrm{mL}\end{array}$ & $\begin{array}{l}\text { Copies/100 } \\
\mathrm{mL}\end{array}$ \\
\hline Replicates & 44 & 56 & 40 & 21 & 36 & 3 & 9 & 8 & 71 \\
\hline Source water & SW, GW & SW, GW & SW, GW & SW, GW & NA & NA & NA & NA & SW \\
\hline Treatment type(s) & $\begin{array}{l}\text { 5-stage BF, } \\
\text { AS, DN }\end{array}$ & $\begin{array}{l}\text { 4-stage BF, } \\
\text { UV, bio- } \\
\text { filter }\end{array}$ & $\begin{array}{l}\text { Dual media } \\
\text { filter, MB }\end{array}$ & $\begin{array}{l}\text { Dual media } \\
\text { filter }\end{array}$ & NA & NA & $\begin{array}{l}\text { Sed., SF, } \\
\text { PAC, GAC, } \\
\mathrm{O}_{3}\end{array}$ & NA & NA \\
\hline Pipe material(s) & NA & NA & NA & NA & NA & NA & NA & NA & NA \\
\hline Disinfectant & $\mathrm{NH}_{2} \mathrm{Cl}$ & $\mathrm{Cl}_{2}$ & $\mathrm{NH}_{2} \mathrm{Cl}$ & $\mathrm{Cl}_{2}$ & $\mathrm{Cl}_{2}$ & $\mathrm{NH}_{2} \mathrm{Cl}$ & NA & $\mathrm{NH}_{2} \mathrm{Cl}$ & NA \\
\hline \multicolumn{10}{|l|}{$\begin{array}{l}\text { Observed mean } \\
\text { absolute abundance } \\
\text { of target genes } \\
\text { ( } \log _{10} \text { scale) }\end{array}$} \\
\hline 16S rRNA & 4.2 & $2.3-3.3$ & 4.2 & 3.5 & - & 6.0 & $7.0-7.6$ & $5.4-7.0$ & $5.2-7.4$ \\
\hline$b / a_{\mathrm{TEM}}$ & 1.8 & 1.7 & 1.5 & 1.6 & $3.5-5.5$ & - & - & $2.2-3.4$ & $2.0-5.0$ \\
\hline$b / a_{\mathrm{SHV}}$ & - & - & - & - & - & - & - & $0-1.5$ & - \\
\hline erm B & - & - & - & - & $2.5-3.8$ & - & \begin{tabular}{|l|}
$5.0-5.5$ \\
\end{tabular} & - & ND-5.0 \\
\hline int/1 & 4.7 & 4.9 & 4.2 & ND & - & - & - & - & $2.0-4.5$ \\
\hline $\operatorname{tet}(\mathrm{M})$ & - & - & - & - & $2.0-5.4$ & - & 5.5 & - & - \\
\hline $\operatorname{tet}(\mathrm{W})$ & - & - & - & - & - & - & $5.6-5.8$ & - & ND-4.5 \\
\hline $\operatorname{tet}(\mathrm{X})$ & - & - & - & - & $2.2-3.8$ & - & ND & - & - \\
\hline qnrA & 1.2 & ND & ND & 2.1 & $2.0-3.6$ & - & ND & - & - \\
\hline qnrs & - & - & - & - & - & - & 5.0 & - & - \\
\hline sul1 & 2.7 & $1.2-1.7$ & 3.2 & 2.1 & $4.6-6.8$ & 2.1 & 7.5 & $0.9-3.2$ & $3.0-6.0$ \\
\hline sul2 & - & - & - & - & $3.5-5.8$ & - & 6.0 & $0.1-4.2$ & ND-5.7 \\
\hline vanA & 1.4 & 1.9 & 1.5 & 1.3 & $0-2.5$ & - & - & - & - \\
\hline
\end{tabular}


$A S$, activated sludge; $B F$, Bardenpho; $G A C$, granular activated carbon; $P A C$, powdered activated carbon; $M B$, membrane bioreactor; O3, ozone; Sed., sedimentation; SF, sand filter; UV, ultraviolet disinfection; NA, not available; ND, no detection; "-", no measurement or value; $q P C R$, quantitative PCR. Mean abundance values for target genes were adapted from source article(s) text or approximated from figures

Studies documenting the occurrence and abundance of ARGs are important for developing effective monitoring strategies for controlling microbial drinking water quality. Total bacterial biomass (e.g., 16S rRNA) can range several orders of magnitude ( 103-10 10 copies/L) in drinking water (Table 1, Xi et al. [170]; Garner et al. [47]; Garner et al. [46]). ARGs including beta-lactamase resistance genes (b/a (TEM), sulfonamide genes (sul1 and sul2), tetracycline resistance genes $(\operatorname{tet}(\mathrm{W})$, tet $(\mathrm{M})$, tet $(\mathrm{X}))$, and the integrase gene of class 1 integrons (int/1) have been quantified in DWDS at concentrations ranging from approximately $10^{1}$ to $10^{7}$ copies/L (Table 1 , Xi et al. [170]; Garner et al. [45]; Su et al. [154]; Hao et al. [57]; Rocha et al. [138]; Zhang et al. [178]). The majority of previous studies focused on measuring ARG abundance in the planktonic phase and did not measure gene concentrations in biofilms or corrosion deposits, which have been cited as important reservoirs for opportunistic pathogens and ARGs (Balcázar et al. [10]). Other studies have utilized high-throughput qPCR (HT-qPCR) for detecting ARGs in DWDS, with detections of over 100 different ARGs, transposases, and integrons in drinking water samples (Xu et al. [174]; Huang et al. [63]; Waseem et al. [166]). These studies and others have observed increases in transposase genes, $\beta$-lactam resistance genes, and MGEs in DWDS water compared to treated drinking water entering the DWDS.

Many environmental factors exist in DWDS that may influence the abundance of ARGs. It is well documented that disinfection practices (e.g., chlorination or chloramination), antibiotics, antimicrobials, and metals may exacerbate the prevalence of antibiotic resistance in engineered systems such as DWDS. However, the fate of ARGs, MRGs, and mechanisms of horizontal gene transfer in full-scale DWDS are not well understood.

Additionally, previous studies have suggested that extracellular DNA may persist in aquatic systems for long periods of time and may represent an important reservoir of ARGs in DWDS (Hao et al. [57]; Sakcham et al. [141]). Due to potential public health implications associated with the presence of opportunistic pathogens, $A R G s$, and MRGs in drinking water, this area of research warrants further investigation.

\section{Plausible Mechanisms for Antibiotic Resistance Selection by Metals in DWDS}

Previous studies on lab-scale and full-scale DWDS have focused on the impact of a variety of factors on microbial ecology in DWDS including pipe materials (Niquette et al. [111]; Lehtola et al. [82]; Proctor et al. [129]; Douterelo et al. [36]), flow regime (Manuel et al. [101]; Lautenschlager et al. [79]), nutrients (Batte et al. [11]), and disinfectant type (chlorine/chloramines) (Wang et al. [165]; Aggarwal et al. [2]; Dai et al. [31]; Waak et al. [163]), but they have seldomly focused specifically on the impact of metals on antibiotic resistance. Drinking water networks are comprised of various metal pipe materials including cast iron, ductile iron (Fe), copper (Cu), brass, and lead $(\mathrm{Pb})$. Metal species such as $\mathrm{Cu}, \mathrm{Fe}$, and $\mathrm{Pb}$ are primarily introduced to drinking water through corrosion processes and leaching of metal ions from plumbing materials (Kang et al. [67]; Kim and Herrera [38]). Zinc $(\mathrm{Zn})$ is present when added as a corrosion inhibitor attached to phosphate (Payne et al. [119]). Additional heavy metals such as aluminum ( $\mathrm{Al}$ ), arsenic (As), chromium ( $\mathrm{Cr}$ ), and uranium (U) present at concentrations below their maximum contaminant levels (MCLs) or at non-detectable levels in treated drinking water can accumulate in deposits and corrosion scales in DWDS (Lytle et al. [95]; Schock et al. [145]; Peng and Korshin [122]; Peng et al. [121]). The primary concern with the presence of trace metals in DWDS is the potential for their release back into finished drinking water, which may result in elevated dissolved metal levels in domestic tap water (Sun et al. [157]). Heavy metals present in drinking water environments at sub-inhibitory concentrations can promote antibiotic resistance and horizontal transfer of ARGs (Baker-Austin et al. [9]; Zhang et al. [179]; Zhang et al. [182]). In addition, positive correlations have previously been observed between 
multiple antibiotic resistance and metal exposure $(\mathrm{Cu}, \mathrm{Pb}, \mathrm{Zn})$ in drinking water point of use samples compared to point of entry to the DWDS, suggesting that bacteria acquired antibiotic resistance inside the DWDS (Calomiris et al. [21]).

Microorganisms have developed a variety of methods for coping with environmental stress, such as exposure to heavy metals. General mechanisms responsible for metal resistance in microbial cells include (i) exclusion by permeability barrier, (ii) active efflux, (iii) intra- and extracellular sequestration, (iv) enzymatic detoxification, and (v) decreased sensitivity of cellular targets to metal ions (Bruins et al. [18]; Harrison et al. [58]). Some microorganisms such as Pseudomonas aeruginosa can upregulate the expression of extracellular polymers or siderophores (metal-chelating agents) in response to metal exposure, which contain functional groups capable of binding to metal ions (Lemire et al. [84]). The role of siderophores is mainly to scavenge Fe, but can also form complexes with other essential metals ( $\mathrm{Mo}, \mathrm{Mn}, \mathrm{Co}$, and $\mathrm{Ni}$ ) and make them available for microbial cells (Ahmed and Holmström [3]). Extracellular polymers and siderophores can precipitate metal ions in the extracellular environment, and soluble siderophores bound to metals may be subject to reduced uptake into microbial cells or increased efflux out of the cell by membrane transporters (Braud et al. [16]; Hannauer et al. [55]). Additionally, biofilms provide an advantageous way for microorganisms to survive on metallic pipes in DWDS, and a previous study reported growth of over $10^{7}$ cells per $\mathrm{cm}^{2}$ after only 30 days on metal pipe materials including stainless steel and copper (Morvay et al. [107]). Molecular mechanisms responsible for stimulating horizontal gene transfer after exposure to metals $(\mathrm{Cu}, \mathrm{Ag}, \mathrm{Cr}$, and $\mathrm{Zn}$ ) include intracellular reactive oxygen species (ROS) formation, SOS response, increased cell membrane permeability, and altered expression of conjugation-relevant genes (Zhang et al. [179]). This study and other studies regarding the potential for horizontal gene transfer following metal ion exposure have suggested that selection mechanisms such as coresistance and cross-resistance likely play a significant role in the development of antibiotic resistance in metalcontaminated environments (Baker-Austin et al. [9]; Seiler and Berendonk [148]; Knapp et al. [72]). In addition to co-resistance and cross-resistance, co-regulatory mechanisms may also promote the co-selection process, which occurs when a single regulatory gene controls multiple resistance genes that confer resistance to different compounds (Pal et al. [115]).

Co-resistance is defined as two or more genetically linked resistance genes, indicating that the genes responsible for two or more resistances are located next to each other on one MGE (Chapman [25]; Ju et al. [66]). Hasman and Aarestrup et al. ([1]) observed a correlation between copper resistance and resistance to macrolides and glycopeptides in Enterococcus faecium obtained from copper-exposed pigs and documented the co-transfer of copper- and macrolide-resistant phenotypes in transconjugants (Aarestrup et al. [1]; Hasman and Aarestrup [62]; Hasman and Aarestrup [61]). The physical linkage results in the co-selection of other genes located on the same genetic element when an organism is exposed to a particular stressor, such as an antimicrobial compound or metal (Baker-Austin et al. [9]; Poole [126]). Even at environmentally relevant and sub-inhibitory concentrations, the presence of metals such as Cu have been positively correlated with ARGs, which is an indication that sublethal levels of Cu can increase ARG prevalence (Knapp et al. [72]; Zhang et al. [182]). The high redox potential of $\mathrm{Cu}$ has also allowed it to serve as an ideal biological co-factor, particularly in aerobic microorganisms (Outten et al. [114]; Rensing and Grass [135]). Previous studies have suggested that subinhibitory levels of copper ions present in DWDS can stimulate growth of microorganisms (Zhang et al. [185]), catalyze decay of disinfectant residuals (chloramines) (Nguyen et al. [110]), and cause microbial community shifts (Proctor et al. [129]; Rhoads et al. [136]). Alternatively, copper and silver ion exposure can inhibit growth of microorganisms such as Legionella pneumophila at concentrations ranging from 0.20 to $4.0 \mathrm{mg} / \mathrm{L}$ (Liu et al. [92]; Kusnetsov et al. [76]; Van Der Kooij et al. [159]) and a strong inhibitory effect on nitrifying bacteria has been reported following copper exposure exceeding $0.90 \mathrm{mg} / \mathrm{L}$ (Zhang et al. [181]). The enrichment of antibioticresistant microorganisms in metal-contaminated environments has been attributed to the selection of organisms harboring resistance genes for both agents (antibiotics and metals) on chromosomes or plasmids 
(Poole [126]). Furthermore, a survey of soils in Scotland demonstrated a significant correlation between $\mathrm{Cu}$ levels and the occurrence of ARGs including erm(B), erm (F), tet(M), and tet(W) (Knapp et al. [73]). This study also revealed positive correlations between $\mathrm{Fe}$ and $\mathrm{Pb}$ in soils and the occurrence of ARGs including tet $(M)$, tet $(W), b_{\text {TEM, }}$ and bla $a_{\mathrm{OXA}}$.

Cross-resistance is primarily observed through multidrug efflux pumps which can rapidly extrude structurally dissimilar compounds out of the cell, such as heavy metals and antibiotics (Baker-Austin et al. [9]; Martinez et al. [103]). Previous research has suggested that the abundance of class 1 integrons observed in metalcontaminated environments were associated with an increase in antibiotic resistance, as class 1 integrons are closely located to genes encoding for the multidrug efflux pump czcA (which can expel $\mathrm{Zn}, \mathrm{Cd}$, and Co) (Seiler and Berendonk [148]). Class 1 integrons are genetic elements capable of acquiring and exchanging DNA fragments called gene cassettes (Hall et al. [53]). The presence of integrons and other MGEs can mediate a selective advantage to microorganisms exposed to stressful environmental conditions (e.g., exposure to metals). Previous studies have observed significant positive correlations between MGEs and ARGs in aquatic environments including bla ${ }_{\mathrm{TEM}}, \operatorname{ermA}$, sul1, tet(O), tet(W), and tet $(\mathrm{X})$ (Pruden et al. [133]; Szekeres et al. [158]; Dong et al. [34]).

Exposure to heavy metals may trigger co-selection responses, but can also increase the level of tolerance to antibiotics due to co-regulation of resistance genes (Seiler and Berendonk [148]). Guo et. al observed an increase in the tetracycline resistance gene $(\operatorname{tet}(\mathrm{Q}))$ in gut microbiota of mice exposed to Fe and suggested that iron exposure alone could potentially alter the diversity and functions of gut microbiota and the abundance of ARGs and MGEs (Guo et al. [52]). Some heavy metals (e.g., Pb) have no known function in bacterial cells but can cause oxidative stress, which could promote generation of ROS and facilitate horizontal gene transfer in the distribution system (Knapp et al. [73]). The dominant mechanisms of co-selection for metal- and antibiotic resistance remain relatively unknown, especially in drinking water environments. Previous studies have suggested that there may be more limited opportunities for metals to drive horizontal gene transfer of antibiotic resistance; however, numerous possibilities exist for metals to select for ARB through chromosomal MRGs (Pal et al. [117]; Pal et al. [115]). Additionally, transposable elements originating in chromosomal DNA can jump to plasmids carrying ARGs and MRGs that can easily be transferred to other microorganisms through transformation or conjugation.

Metal pipe materials, including $\mathrm{Cu}, \mathrm{Fe}$, and Pb commonly used in DWDS including water mains, service connections, and premise plumbing, can influence microbial community composition and the presence of opportunistic pathogens (Rożej et al. [140]; Proctor et al. [129]; Neu et al. [109]). In fact, sub-inhibitory exposure to $\mathrm{Cu}$ and $\mathrm{Zn}$ can stimulate antibiotic resistance in water environments at concentrations below their respective maximum contaminant levels (MCLs) (Fig. 1). While MCLs are based on direct impacts to human health, these data imply that indirect consequences including selection for antibiotic resistance can occur at levels below the MCLs. Co-selection of ARGs and MRGs is likely ubiquitous in full-scale DWDS due to the presence of metals and disinfectants. Several bacteria genera commonly detected in DWDS contain plasmids with both ARGs and MRGs including E. coli, Staphylococcus, Pseudomonas, and Mycobacterium (Pal et al. [116]). Studies regarding the occurrence or distribution of ARGs, MRGs, or MGEs using molecular techniques such as qPCR or droplet digital $P C R$ (ddPCR) are limited. Quantitative measurements of ARB, ARGs, and MRGs in drinking water and biofilms are essential for improving risk assessments for potable water systems. Additionally, fundamental research from laboratory-scale studies and full-scale DWDS surveys providing information on pipe materials and antibiotic resistance are both necessary to better understand how engineering management decisions impact human health. 
$\mathrm{Cu}$

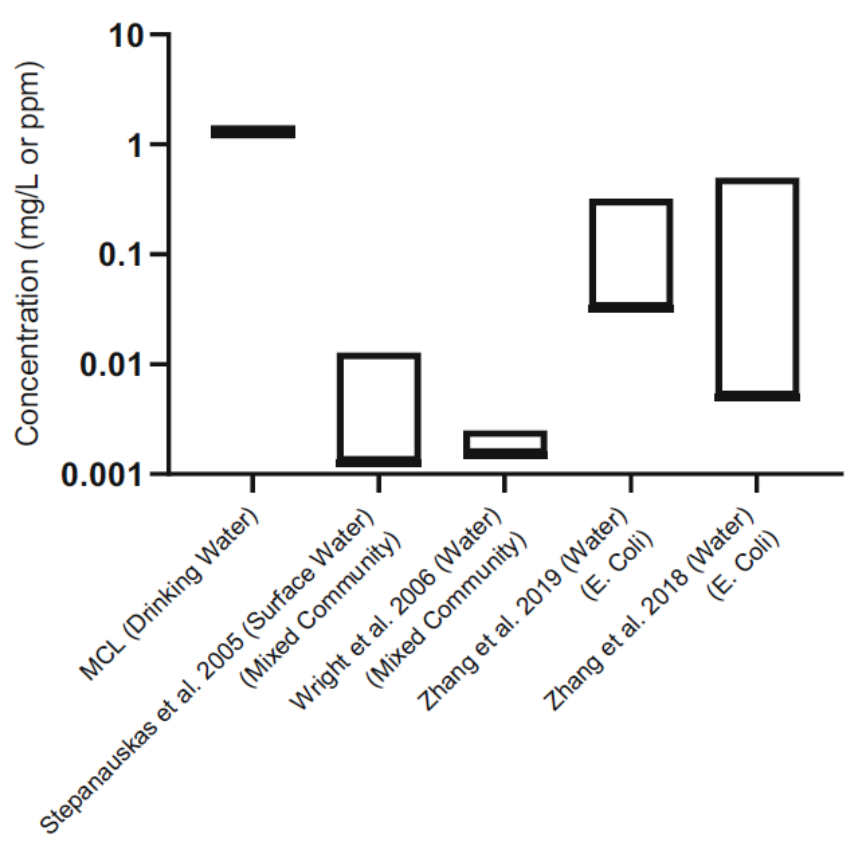

$\mathrm{Zn}$

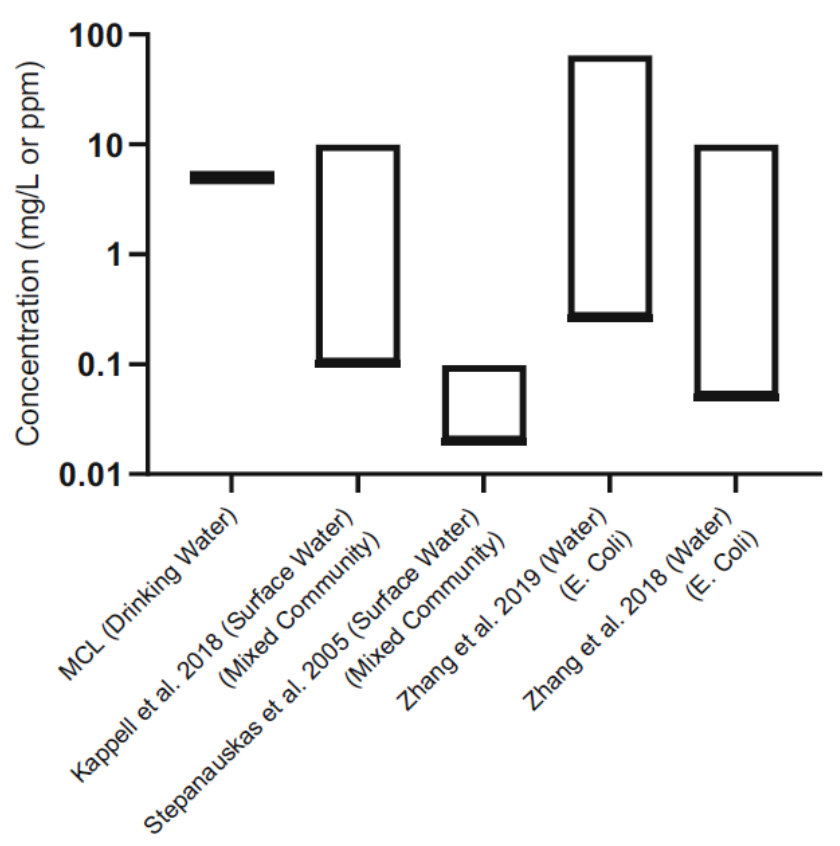

Fig. 1 Studies documenting antibiotic resistance in response to metal exposure in water environments ( $\mathrm{Cu}$ and $\mathrm{Zn}$ ). The US Environmental Protection Agency maximum contaminant level (MCL) for drinking water quality is plotted for reference. References for data in figure (Stepanauskas et al. [153]; Wright et al. [169]; Zhang et al. [182]; Zhang et al. [184]; Kappell et al. [69]; Zhang et al. [180])

\section{Impact of Corrosion Products on Antibiotic Resistance}

Corrosion of drinking water infrastructure occurs due to oxidation processes of metal materials and results in subsequent formation and accumulation of corrosion products on metal surfaces (McNeill and Edwards [105]). Various chemical oxidation processes that occur in drinking water environments can degrade pipe surfaces, valves, and connections, and gradually rust metal surfaces. Corrosion of drinking water pipes is responsible for destruction of the pipe material and also the deterioration of the drinking water quality in the distribution system (Sun et al. [156]). Corrosion scales are formed by the accumulation of corrosion products and other suspended particles on pipe surfaces, which reduces the capacity of the system and provides habitats for potentially pathogenic microorganisms (Wang et al. [165]; Sun et al. [156]).

Corrosion of drinking water pipes can occur due to a variety of circumstances including increased pipe service age, water chemistry, and operational parameters such as stagnation time and flow velocity (Flemming et al. [43]; Lehtola et al. [81]; Xie and Giammar [172]). Passivation of drinking water pipes occurs over time by the formation of corrosion products on pipe surfaces, and the formation of passivating scales in DWDS pipes lowers the potential for metal ions to leach into finished drinking water, but also provides increased surface area for bacterial attachment and biofilm formation (Zhu et al. [187]; Li et al. [86]). Corrosion products are comprised of scale minerals and possibly additional contaminants deposited from drinking water which may impact antibiotic resistance and horizontal gene transfer of ARGs in drinking water systems. Corrosion products that form in iron pipes typically consist of iron (III) oxyhydroxides (e.g., goethite $(\alpha-\mathrm{FeOOH})$, lepidocrocite $(\gamma$-FeOOH)), iron(II, III) oxides (e.g., magnetite $\left.\left(\mathrm{Fe}_{3} \mathrm{O}_{4}\right)\right)$, and/or iron(II) carbonates (e.g., siderite $\left.\left(\mathrm{FeCO}_{3}\right)\right)$ ( $\mathrm{McNeill}$ and Edwards [105]; Peng et al. [123]; Yang et al. [175]). Common lead corrosion products include lead(II) oxides (e.g., litharge ( $\alpha$ $\mathrm{PbO})$ ), lead(II) carbonates (e.g., cerussite $\left(\mathrm{PbCO}_{3}\right)$, hydrocerussite $\left.\left(\mathrm{Pb}_{3}\left(\mathrm{CO}_{3}\right)_{2}(\mathrm{OH})_{2}\right)\right)$, lead (II) phosphates (e.g., hydroxylpyromorphite $\left.\left(\mathrm{Pb}_{5}\left(\mathrm{PO}_{4}\right)_{3} \mathrm{OH}\right)\right)$, and lead (IV) oxides (e.g., scrutinyite $\left(\alpha-\mathrm{PbO}_{2}\right)$, plattnerite $\left.\left(\beta-\mathrm{PbO}_{2}\right)\right)(\mathrm{Lytle}$ 
and Schock [94]; Schock et al. [147]; Schock et al. [146]; Kim and Herrera [38]; Xie and Giammar [172]). Compared to iron and lead focused work, very few studies have investigated copper corrosion under conditions relevant to drinking water distribution, and cuprous oxide $\left(\mathrm{Cu}_{2} \mathrm{O}\right)$ and/or cupric oxide $(\mathrm{CuO})$ are considered the dominant copper corrosion products (Feng et al. [42]; McNeill and Edwards [106]; Xiao et al. [171]; Kang et al. [67]; Lytle and Nadagouda [93]). Furthermore, there is a paucity of research regarding the impacts of these metal corrosion products on microbial growth, ecology, and potential selection for antibiotic resistance in DWDS.

Formation of drinking water corrosion products is extremely heterogeneous and is strongly affected by water chemistry parameters, such as $\mathrm{pH}$, dissolved inorganic carbon, dissolved oxygen, disinfectant type, natural organic matter, and use of corrosion inhibitors (Volk et al. [162]; Sarin et al. [143]; Xie et al. [173]; Noel et al. [112]). For instance, $\mathrm{PbO}_{2}$ has been observed as a common lead corrosion product in various distribution systems that use free chlorine as the disinfectant, while lead(II) phosphates have been identified as the predominant corrosion products in systems using phosphate corrosion inhibitors (Lytle and Schock [94]; Kim and Herrera [38]). Furthermore, corrosion products in DWDS can exhibit significantly different morphological and structural composition and be sinks for various inorganic contaminants such as $\mathrm{As}, \mathrm{Cd}, \mathrm{Cr}$, manganese (Mn), nickel (Ni), and vanadium (V) (Schock et al. [145]; Peng and Korshin [122]; Gerke et al. [48]). For example, some common iron corrosion products, such as goethite, lepidocrocite, and magnetite have strong affinities to adsorb and concentrate trace heavy metals present in drinking water (Sarin et al. [144]; Peng et al. [123]). Consequently, the corrosion products and additional contaminants that accumulate from drinking water on biofilms and pipe surfaces may subsequently impact the distribution and abundance of ARB and ARGs present in drinking water systems.

Similar to dissolved and particulate metals in aquatic environments, exposure of bacteria to corrosion products in DWDS may alter microbial communities and increase the potential for horizontal gene transfer of ARGs and MRGs. Previous studies have suggested that exposure of microbial populations to metal pipe materials and corrosion scales that accumulate in DWDS may eliminate some microorganisms while allowing metal-tolerant organisms to survive, which can potentially disseminate bacteria resistant to both metals and antibiotics in finished drinking water (Calomiris et al. [21]; Baker-Austin et al. [9]). Furthermore, a previous study demonstrated that exposure to cuprous oxide resulted in bacteriostatic effects against gram-positive bacteria (Bacillus subtilis, Staphylococcus aureus, Streptococcus faecalis) and gram-negative bacteria including Pseudomonas aeruginosa and Enterobacter cloacae (Pang et al. [118]). Exposure of bacterial populations to copper corrosion products such as cuprous oxide and cupric oxide could increase selection for copper-related resistance genes and ARGs in organisms harboring resistance genes for both agents (Aruoja et al. [6]; Pang et al. [118]; Hans et al. [56]; Poole [126]). For example, the presence of $\mathrm{Cu}^{2+}$ ions and $\mathrm{CuO}$ nanoparticles (1-100 $\mu \mathrm{mol} / \mathrm{L})$ increased the conjugative transfer of ARGs across bacterial genera, increased cell membrane permeability, and caused the overproduction of ROS (Zhang et al. [180]). Bacterial exposure to CuO nanoparticles at sub-inhibitory levels resulted in expression of stress response genes including $d p s, \operatorname{sod} A, \operatorname{sod} B, \operatorname{trx} C, k a t E$, and katG (Zhang et al. [180]). Additionally, corrosion scales provide bacteria with organic matter and nutrients, consume residual disinfectant concentrations, provide increased surface area for bacterial adsorption, and provide iron oxides as potential electron acceptors that may increase bacterial activity (Appenzeller et al. [5]; Jang et al. [64]). Consequently, bacterial exposure to corrosion scales in DWDS containing copper and iron oxides may increase bacterial growth and selection for bacteria harboring ARGs and MRGs in finished drinking water.

There has been limited research conducted regarding different corrosion products and their effects on the abundance of ARB, ARGs, or MRGs in biofilms and drinking water in DWDS. Laboratory-scale studies are needed to understand the fundamental impacts of different corrosion products such as copper oxides and iron oxides on 
microbial communities and the antibiotic resistome. Full-scale studies are necessary to characterize the distribution of different corrosion products, resistance genes, and microbial communities in full-scale DWDS. Understanding the relationship of corrosion products and antibiotic resistance could provide critical information necessary to improve decisions regarding the selection of pipe materials for potable water systems.

\section{Impact of Corrosion Inhibitors on Antibiotic Resistance}

Optimized corrosion control treatment (OCCT) is a specific requirement of the Lead and Copper Rule (LCR) introduced in 1991 by the US Environmental Protection Agency (US EPA) (Brown et al. [17]). Drinking water utilities have three options for corrosion control treatment including adjusting the $\mathrm{pH}$ and alkalinity of drinking water, developing $\mathrm{Pb}(\mathrm{IV})$ scale by maintaining free chlorine residuals throughout the distribution system, and using corrosion inhibitors such as orthophosphate or sodium silicates (Brown et al. [17]). Corrosion inhibitors commonly applied in drinking water systems include polyphosphates, orthophosphate, zinc orthophosphate, and sodium silicates (Edwards and McNeill [39]; Schock et al. [146]; Cartier et al. [24]). Recent studies have cited the potential for phosphate-containing corrosion inhibitors to serve as a nutrient source for bacterial growth, which has raised concerns in some US drinking water utilities (Edwards and McNeill [39]; Fang et al. [41]). Therefore, it is important to gain a better understanding of the impacts of different corrosion inhibitors on microbial ecology and the abundance of ARGs and MRGs in full-scale DWDS.

A national survey of water utilities revealed that over $50 \%$ of utilities used phosphate inhibitors, and zinc orthophosphates were the most common phosphates applied (McNeill and Edwards [104]) with over half of utilities reporting doses between 0.7 and $2 \mathrm{mg} / \mathrm{L}$ as phosphate (McNeill and Edwards [104]). Bacteria typically require a ratio for C:N:P of approximately 100:10:1, and many DWDS are P deficient (LeChevallier et al. [80]; Brown et al. [17]). Research regarding the effects of phosphate addition on drinking water microbial communities has yielded mixed results. Several studies have reported increased bacterial growth in drinking water systems with phosphate exposure levels ranging from 0.001 to $0.03 \mathrm{mg} / \mathrm{L}$ P (Lehtola et al. [83]; Chu et al. [26]; Fang et al. [41]; Payne et al. [119]). Phosphorus addition to drinking water can promote biofilm cell growth, decrease EPS production, and induce biofilms with increased thickness and biomass (Fang et al. [41]). By stimulating microbial growth in drinking water biofilms, phosphorus addition may also lead to increased abundance of ARB and ARGs. Polyphosphate addition to drinking water may impact biofilm growth resulting in softer, thicker biofilms that are more prone to detachment (Shen et al. [151]). Furthermore, the addition of polyphosphate can supply nutrients to bacteria for biofilm development, play an important role in bacteria metabolic regulation, and increase bacterial resistance to environmental stress (Rao and Kornberg [134]; Gangaiah et al. [44]). Zinc orthophosphate addition has been shown to increase microbial community diversity in drinking water biofilms (Payne et al. [119]). Another study reported that phosphate addition did not increase total biomass in biofilm communities, but did cause shifts in microbial community composition (Batté et al. [12]). Similarly, Jang et al. observed increased community richness and diversity in biofilms that developed on stainless steel and ductile cast iron coupons with phosphate addition compared to controls without phosphate addition (Jang et al. [64]). The use of zinc orthophosphate for corrosion control may also result in the selection of resistant microorganisms in DWDS due to the potential for zinc to select for ARGs and MRGs (Peltier et al. [120]; Kappell et al. [69]). As a result, the use of orthophosphate and zinc orthophosphate as corrosion inhibitors influences microbial ecology and may also impact the abundance and distribution of resistance genes in DWDS. However, limited research has been conducted regarding the effects of different corrosion inhibitor treatments on the presence of ARB, ARGs, and MRGs in full-scale DWDS.

Sodium silicates are an alternative to phosphate-based corrosion inhibitors and have been reported to be an effective strategy for lead control in some systems since the 1920s (Butler and Ison [19]; Schock et al. [146]; Lintereur et al. [89]). Similar to polyphosphates, the molecular composition of sodium silicates are 
indeterminate, with the chemical formula $\left(\mathrm{Na}_{2} \mathrm{O}: \mathrm{n}\left(\mathrm{SiO}_{2}\right)\right.$, where $n$ is a variable ratio (Crittenden et al. [29]). Typical dosages of silicates range from 4 to $30 \mathrm{mg} / \mathrm{L}$ as $\mathrm{SiO}_{2}$, and higher doses are required for drinking water with higher hardness, higher chlorides, and/or higher dissolved solids (Lane et al. [77]). Silicates and phosphates act as anodic inhibitors when used at low doses for corrosion control treatment of drinking water, which reduces corrosion by forming a protective layer of oxide film on pipe surfaces. The Illinois State Water Survey conducted extensive testing with corrosion inhibitors and recommended that silicates were the best option for corrosion inhibition in galvanized steel and copper-based piping commonly used in domestic hot water systems (Lane et al. [77]). The use of sodium silicates may have advantages over phosphate-based treatments due to the lack of phosphorus and zinc, which could potentially limit microbial growth and levels of ARGs in finished drinking water. A previous study observed decreased average bacterial growth (e.g., lower ATP concentrations) in biofilms subjected to sodium silicate treatment compared to phosphate-containing corrosion inhibitors, but the differences were not statistically significant (Kogo et al. [74]). Additionally, Rompré et al. ([139]) compared heterotrophic plate counts (HPC) between sodium silicate and phosphate treatments in a study conducted with laboratory-scale annular reactors and in a confined section of a full-scale DWDS, but reported no significant differences between corrosion control treatments (Rompré et al. [139]). This study also concluded that surface material (unlined gray iron vs. polycarbonate) was a larger factor influencing biofilm development in DWDS pipes compared to corrosion inhibitor type. Despite previous analysis of corrosion inhibitors in DWDS, the impact of corrosion inhibitor type on the abundance of ARB, ARGs, and MRGs has yet to be elucidated in fullscale systems. Laboratory-scale and full-scale studies investigating the impacts of corrosion inhibitors and their impacts on the development of corrosion products and microbial communities are needed to better understand mechanisms of antibiotic resistance selection in DWDS.

Little information exists regarding the impacts of sodium silicates on microbial ecology and the proliferation of antibiotic resistance in full-scale drinking water systems. A previous study investigated the effects of sodium silicate addition on cucumber seedling growth and resistance to the soil-borne pathogen Fusarium oxysporum $\mathrm{f}$. sp. cucumerinum Owen (Zhou et al. [186]). The study reported changes in bacterial and fungal community structure in response to two $\mathrm{mM}$ sodium silicate addition in addition to decreased abundance of microbial taxa containing pathogens (Zhou et al. [186]). Consequently, the addition of sodium silicates to drinking water for corrosion control may also impact bacterial community composition but has yet to be investigated. In order to mitigate public health impacts related to corrosion of drinking water infrastructure, future studies should consider the impacts of different corrosion inhibitor regimes on microbial ecology and the abundance of ARGs and MRGs in drinking water systems.

\section{Conclusions and Future Research Recommendations}

Several studies have documented the presence, though not necessarily the quantity, of ARB and ARGs in drinking water environments. Factors such as metal pipe materials, corrosion inhibitors, and corrosion products that develop in full-scale DWDS may select for bacteria harboring resistance to both metals and antibiotics. There is a lack of information regarding the abundance and fate of ARB, ARGs, MRGs, and MGEs in different phases of DWDS including planktonic, biofilm, suspended solids, and loose corrosion deposits. Previous research has demonstrated that water quality deterioration in DWDS can result in increased levels of ARB and ARGs in consumer tap water, which poses a risk to human health.

Future research on antibiotic resistance in DWDS should focus on monitoring the occurrence, fate, and distribution of ARB, ARGs, MRGs, and MGEs in multiple phases in full-scale systems. This information is critical for gaining a better understanding of the prevalence of antibiotic resistance in engineered systems capable of directly impacting human health. Previous characterization of DWDS has primarily focused on microorganisms in the planktonic phase and studies documenting and quantifying ARB, ARGs, or MRGs in drinking water biofilms 
are lacking. Drinking water biofilms have been cited as important reservoirs for opportunistic pathogens and horizontal gene transfer of ARGs (Wingender and Flemming [168]; Balcázar et al. [10]); however, the dominant pathways of antibiotic resistance selection in drinking water are not well documented. In addition to full-scale studies, laboratory-scale studies are needed to distinguish the impacts of different pipe materials, corrosion inhibitors, and corrosion products on the abundance of resistance genes in drinking water and biofilms. These studies will provide critical information regarding the relationship of different system parameters and mechanisms of antibiotic resistance selection in engineered systems. Locations with high densities of bacteria, such as drinking water biofilms, provide conditions which are suitable for proliferation and exchange of resistance genes, and selective pressures (e.g., metals) may increase the abundance of resistance genes in these communities. Additional research is needed to address the research gaps related to the fate and transport of clinically relevant resistance genes in DWDS.

Fundamental information regarding the impacts of pipe materials, metals, and corrosion inhibitors on pathogens and abundance of resistance genes in DWDS is necessary to reduce the prevalence of antibiotic resistance in drinking water. Different pipe materials used in full-scale DWDS may influence the composition of microbial communities and associated resistance genes that can subsequently be transferred to humans through dermal contact, consumption of contaminated drinking water, or inhalation of aerosols during bathing (Falkinham [40]; Garner et al. [47]). Further research including QMRA is needed to determine the concentration of ARB or ARGs that may translate to human health risks (Ashbolt et al. [7]). Research that links ARGs to hosts and distinguishes extracellular DNA from intracellular DNA is also needed (Rice et al. [137]). Furthermore, limited availability of exposure assessments and dose-response data regarding ARB and ARGs for different scenarios hinder the implementation of QMRA approach for evaluating human health risks in aquatic environments (Amarasiri et al. [4]).

The selection of target genes is also important for improving routine monitoring of ARGs, MRGs, and MGEs in full-scale distribution systems. Future research and microbial surveillance efforts should consider monitoring clinically relevant ARGs and other genes commonly linked to horizontal gene transfer processes including betalactam resistance genes, int/1 and sul1 (WHO [167]; Gillings et al. [49]; Ma et al. [96]). The prevalence of dissolved, particulate, and solid phase metals in DWDS warrants further investigation regarding their potential for selection of resistance genes in drinking water biofilms. Additionally, the collection of samples from multiple locations (biofilm/pipe surfaces, corrosion tubercles, under tubercles) within the same distribution system or even the same pipe would increase knowledge regarding impacts of biogeographical heterogeneity in drinking water biofilms on antibiotic resistance (Liu et al. [90]; Gomez-Smith et al. [50]; Neu et al. [109]; Cruz et al. [30]). Laboratory and full-scale studies regarding pipe materials, corrosion inhibitors, and corrosion products are important for gaining insights into microbial functions and could be used to provide guidance to water utilities for making engineering decisions in DWDS that could reduce human health risks.

\section{Funding information}

LK was funded by the Arthur J. Schmitt Fellowship and the Marquette University Water Quality Center.

\section{Authors' contributions}

L.K. and P.M. contributed to the study conception and design. Literature review, data collection, and analysis were performed by LK. The first draft of the manuscript was written by LK and all authors commented on previous versions of the manuscript. All authors read and approved the final manuscript. 


\section{Compliance with ethical standards}

\section{Conflict of interest}

The authors declare that they have no conflict of interest.

\section{Ethical approval}

This article does not contain any studies with human participants or animals performed by any of the authors.

\section{References}

Aarestrup FM, Hasman H, Jensen LB, Moreno M, Herrero IA, Domínguez L, Finn M, Franklin A. Antimicrobial resistance among Enterococci from pigs in three European countries. Appl Environ Microbiol. 2002; 68: 4127-4129. 10.1128/AEM.68.8.4127124043

Aggarwal S, Gomez-Smith CK, Jeon Y, LaPara TM, Waak M, Hozalski RM. Effects of chloramine and coupon material on biofilm abundance and community composition in bench-scale simulated water distribution systems and comparison with full-scale water mains. Environ Sci Technol. 2018; 52; 22: 13077-13088. 10.1021/acs.est.8b02607

Ahmed E, Holmström SJM. Siderophores in environmental research: roles and applications. Microb Biotechnol. 2014; 7: 196-208. 10.1111/1751-7915.121173992016

Amarasiri M, Sano D, Suzuki S. Understanding human health risks caused by antibiotic resistant bacteria (ARB) and antibiotic resistance genes (ARG) in water environments: current knowledge and questions to be answered. Crit Rev Environ Sci Technol. 2019; 0: 1-44. 10.1080/10643389.2019.1692611

Appenzeller BMR, Duval YB, Thomas F, Block JC. Influence of phosphate on bacterial adhesion onto iron oxyhydroxide in drinking water. Environ Sci Technol. 2002; 36: 646-652. 10.1021/es010155m

Aruoja V, Dubourguier HC, Kasemets K, Kahru A. Toxicity of nanoparticles of CuO, $\mathrm{ZnO}$ and $\mathrm{TiO} 2$ to microalgae Pseudokirchneriella subcapitata. Sci Total Environ. 2009; 407: 1461-1468.

10.1016/j.scitotenv.2008.10.053

Ashbolt NJ, Amézquita A, Backhaus T, Borriello P, Brandt KK. Review human health risk assessment (HHRA) for environmental development and transfer of antibiotic resistance. Environ Health Perspect. 2013; 121: 993-1001. 10.1289/ehp.1206316

Auerbach EA, Seyfried EE, McMahon KD. Tetracycline resistance genes in activated sludge wastewater treatment plants. Water Res. 2007; 41: 1143-1151. 10.1016/j.watres.2006.11.045

Baker-Austin C, Wright MS, Stepanauskas R, McArthur JV. Co-selection of antibiotic and metal resistance. Trends Microbiol. 2006; 14: 176-182. 10.1016/j.tim.2006.02.006

Balcázar JL, Subirats J, Borrego CM. The role of biofilms as environmental reservoirs of antibiotic resistance. Front Microbiol. 2015; 6: 1-9. 10.3389/fmicb.2015.01216

Batte M, Appenzeller BMR, Grandjean D, Fass S, Gauthier V, Jorand F, Mathieu L, Boualam M, Saby S, Block JC. Biofilms in drinking water distribution systems. Rev Environ Sci Bio/Technol. 2003; 2: 147-168. 10.1023/B:RESB.0000040456.71537.29

Batté $M$, Mathieu L, Laurent $P$, Prévost $M$. Influence of phosphate and disinfection on the composition of biofilms produced from drinking water, as measured by fluorescence in situ hybridization. Can J Microbiol. 2003; 49: 741-753. 10.1139/w03-094

Bédard E, Laferrière C, Déziel E, Prévost M. Impact of stagnation and sampling volume on water microbial quality monitoring in large buildings. PLoS One. 2018; 13: 1-14. 10.1371/journal.pone.0199429

Bergeron S, Boopathy R, Nathaniel R, Corbin A, LaFleur G. Presence of antibiotic resistant bacteria and antibiotic resistance genes in raw source water and treated drinking water. Int Biodeterior Biodegrad. 2015; 102 : 370-374. 10.1016/j.ibiod.2015.04.017

Berry D, Xi C, Raskin L. Microbial ecology of drinking water distribution systems. Curr Opin Biotechnol. 2006; 17: 297-302. 10.1016/j.copbio.2006.05.007

Braud A, Hannauer M, Mislin GLA, Schalk IJ. The Pseudomonas aeruginosa pyochelin-iron uptake pathway and its metal specificity. J Bacteriol. 2009; 191: 3517-3525. 10.1128/JB.00010-092681917 
Brown RA, McTigue NE, Cornwell DA. Strategies for assessing optimized corrosion control treatment of lead and copper. J Am Water Works Assoc. 2013; 105: 62-75. 10.5942/jawwa.2013.105.0066

Bruins MR, Kapil S, Oehme FW. Microbial resistance to metals in the environment. Ecotoxicol Environ Saf. 2000; 45: 198-207. 10.1006/eesa.1999.1860

Butler G, Ison HCK (1966) Corrosion and its prevention in waters

Cacace D, Fatta-Kassinos D, Manaia CM, Cytryn E, Kreuzinger N, Rizzo L, Karaolia P, Schwartz T, Alexander J, Merlin C, Garelick H, Schmitt H, de Vries D, Schwermer CU, Meric S, Ozkal CB, Pons M-N, Kneis D, Berendonk TU. Antibiotic resistance genes in treated wastewater and in the receiving water bodies: a pan-European survey of urban settings. Water Res. 2019; 162: 320-330. 10.1016/j.watres.2019.06.039

Calomiris JONJ, Armstrong JL, Seidler RJ. Association of metal tolerance with multiple antibiotic resistance of bacteria isolated from drinking water. Appl Environ Microbiol. 1984; 47: 1238-1242. 10.1128/AEM.47.6.1238-1242.1984

Carey DE, McNamara PJ. The impact of triclosan on the spread of antibiotic resistance in the environment. Front Microbiol. 2015; 5: 1-11. 10.3389/fmicb.2014.00780

Carey DE, Zitomer DH, Hristova KR, Kappell AD, McNamara PJ. Triclocarban influences antibiotic resistance and alters anaerobic digester microbial community structure. Environ Sci Technol. 2016; 50: 126-134. 10.1021/acs.est.5b03080

Cartier C, Nour S, Richer B, Deshommes E, Prévost M. Impact of water treatment on the contribution of faucets to dissolved and particulate lead release at the tap. Water Res. 2012; 46: 5205-5216. 10.1016/j.watres.2012.07.002

Chapman JS. Disinfectant resistance mechanisms, cross-resistance, and co-resistance. Int Biodeterior Biodegrad. 2003; 51: 271-276. 10.1016/S0964-8305(03)00044-1

Chu C, Lu C, Lee C. Effects of inorganic nutrients on the regrowth of heterotrophic bacteria in drinking water distribution systems. J Environ Manag. 2005; 74: 255-263. 10.1016/j.jenvman.2004.09.007

Ciric L, Mullany P, Roberts AP. Antibiotic and antiseptic resistance genes are linked on a novel mobile genetic element: Tn6087. J Antimicrob Chemother. 2011; 66: 2235-2239. 10.1093/jac/dkr3113172042

Courvalin P. Transfer of antibiotic resistance genes between gram-positive and gram-negative bacteria. Antimicrob Agents Chemother. 1994; 38: 1447-1451. 10.1128/AAC.38.7.1447284573

Crittenden JC, Trussel RR, Hand DW, Howe KJ, Tchobanoglous G (2012) MWH's water treatment: principles and design, 3rd Editio. John Wiley \& Sons Inc.

Cruz MC, Woo Y, Flemming H, Wuertz S. Nitrifying niche differentiation in biofilms from full-scale chloraminated drinking water distribution system. Water Res. 2020; 176: 115738. 10.1016/j.watres.2020.115738

Dai Z, Sevillano-Rivera MC, Calus ST, los Santos QMB, Eren AM, vander Wielen PWJJ, ljaz UZ, Pinto AJ (2019) Disinfection exhibits systematic impacts on the drinking water microbiome. Microbiome 828970 $10.1101 / 828970$

Di Cesare A, Eckert EM, D'Urso S, Bertoni R, Gillan DC, Wattiez R, Corno G. Co-occurrence of integrase 1, antibiotic and heavy metal resistance genes in municipal wastewater treatment plants. Water Res. 2016; 94: 208-214. 10.1016/j.watres.2016.02.049

Di Cesare A, Eckert EM, Teruggi A, Fontaneto D, Bertoni R, Callieri C, Corno G. Constitutive presence of antibiotic resistance genes within the bacterial community of a large subalpine lake. Mol Ecol. 2015; 24: 38883900. 10.1111/mec.13293

Dong $\mathrm{P}$, Wang $\mathrm{H}$, Fang $\mathrm{T}$, Wang $\mathrm{Y}, \mathrm{Ye} \mathrm{Q}$. Assessment of extracellular antibiotic resistance genes (eARGs) in typical environmental samples and the transforming ability of eARG. Environ Int. 2019; 125: 90-96. 10.1016/j.envint.2019.01.050

Douterelo I, Boxall JB, Deines P, Sekar R, Fish KE, Biggs CA. Methodological approaches for studying the microbial ecology of drinking water distribution systems. Water Res. 2014; 65: 134-156. 10.1016/j.watres.2014.07.008

Douterelo I, Dutilh BE, Arkhipova K, Calero C, Husband S. Microbial diversity, ecological networks and functional traits associated to materials used in drinking water distribution systems. Water Res. 2020; 173: 115586. 10.1016/j.watres.2020.115586 
Douterelo I, Husband S, Loza V, Boxall J. Dynamics of biofilm regrowth in drinking water distribution systems. Appl Environ Microbiol. 2016; 82: 4155-4168. 10.1128/AEM.00109-164959196

Kim EJ, Herrera JE. Characteristics of lead corrosion scales formed during drinking water distribution and their potential influence on the release of lead and other contaminants. Environ Sci Technol. 2010; 44: 60546061. 10.1021/es101328u

Edwards M, McNeill LS. Effect of phosphate inhibitors on lead release from pipes. J Am Water Works Assoc. 2002; 94: 79-90. 10.2307/41297947

Falkinham JO. Surrounded by mycobacteria: nontuberculous mycobacteria in the human environment. J Appl Microbiol. 2009; 107: 356-367. 10.1111/j.1365-2672.2009.04161.x

Fang W, Hu JY, Ong SL. Influence of phosphorus on biofilm formation in model drinking water distribution systems. J Appl Microbiol. 2009; 106: 1328-1335. 10.1111/j.1365-2672.2008.04099.x

Feng Y, Teo W-K, Siow K-S, Tan K-L, Hsieh A-K. The corrosion behaviour of copper in neutral tap water. Part I: corrosion mechanisms. Corros Sci. 1996; 38: 369-385. 10.1016/0010-938X(96)00110-2

Flemming HC, Percival SL, Walker JT. Contamination potential of biofilms in water distribution systems. Water Sci Technol Water Supply. 2002; 2: 271-280. 10.1016/S0043-1354(00)00187-1

Gangaiah D, Kassem II, Liu Z, Rajashekara G. Importance of polyphosphate kinase 1 for Campylobacter jejuni viable-but-nonculturable cell formation, natural transformation, and antimicrobial resistance. Appl Environ Microbiol. 2009; 75: 7838-7849. 10.1128/AEM.01603-092794102

Garner E, Chen C, Xia K, Bowers J, Engelthaler D, McLain J, Edwards MA, Pruden A. Metagenomic characterization of antibiotic resistance genes in full-scale reclaimed water distribution systems and corresponding potable systems. Environ Sci Technol. 2018; 44; 16: 6054-6056. 10.1021/acs.est.7b05419

Garner E, Inyang M, Garvey E, Parks J, Glover C, Dickenson E, Sutherland J, Salveson A, Edwards MA, Pruden A. Impact of blending for direct potable reuse on premise plumbing microbial ecology and regrowth of opportunistic pathogens and antibiotic resistant bacteria. Water Res. 2019; 151: 75-86. 10.1016/j.watres.2018.12.003

Garner E, Mclain J, Bowers J, Engelthaler DM, Edwards MA, Pruden A (2018b) Microbial ecology and water chemistry impact regrowth of opportunistic pathogens in full-scale reclaimed water distribution systems. Environ Sci Technol. 10.1021/acs.est.8b02818

Gerke TL, Little BJ, Barry Maynard J. Manganese deposition in drinking water distribution systems. Sci Total Environ. 2016; 541: 184-193. 10.1016/j.scitotenv.2015.09.054

Gillings MR, Gaze WH, Pruden A, Smalla K, Tiedje JM, Zhu YG. Using the class 1 integron-integrase gene as a proxy for anthropogenic pollution. ISME J. 2015; 9: 1269-1279. 10.1038/ismej.2014.226

Gomez-Smith CK, Lapara TM, Hozalski RM. Sulfate reducing bacteria and mycobacteria dominate the biofilm communities in a chloraminated drinking water distribution system. Environ Sci Technol. 2015; 49: 84328440. 10.1021/acs.est.5b00555

Guo J, Li J, Chen H, Bond PL, Yuan Z. Metagenomic analysis reveals wastewater treatment plants as hotspots of antibiotic resistance genes and mobile genetic elements. Water Res. 2017; 123: 468-478. 10.1016/j.watres.2017.07.002

Guo X, Liu S, Wang Z, Xiang ZX, Li M, Wu B. Metagenomic profiles and antibiotic resistance genes in gut microbiota of mice exposed to arsenic and iron. Chemosphere. 2014; 112: 1-8. 10.1016/j.chemosphere.2014.03.068

Hall RM, Collis CM, Kim MJ, Partridge SR, Recchia GD, Stokes HW. Mobile gene cassettes and integrons in evolution. Ann N Y Acad Sci. 1999; 870: 68-80. 10.1111/j.1749-6632.1999.tb08866.x

Hallam N, West J, Forster C, Simms J. The potential for biofilm growth in water distribution systems. Water Res. 2001; 35: 4063-4071. 10.1016/S0043-1354(01)00248-2

Hannauer M, Braud A, Hoegy F, Ronot P, Boos A, Schalk IJ. The PvdRT-OpmQ efflux pump controls the metal selectivity of the iron uptake pathway mediated by the siderophore pyoverdine in Pseudomonas aeruginosa. Environ Microbiol. 2012; 14: 1696-1708. 10.1111/j.1462-2920.2011.02674.x

Hans M, Erbe A, Mathews S, Chen Y, Solioz M, Mücklich F. Role of copper oxides in contact killing of bacteria. Langmuir. 2013; 29: 16160-16166. 10.1021/la404091z 
Hao H, Yang SD, Yang D, Wei YZ, Gang QZ, Li LW, Qiang SZ, Yin J, Ran WH, Wen L, Wang H, Jin M. Profiling of intracellular and extracellular antibiotic resistance genes in tap water. J Hazard Mater. 2019; 365: 340345. 10.1016/j.jhazmat.2018.11.004

Harrison JJ, Tremaroli V, Stan MA, Chan CS, Vacchi-Suzzi C, Heyne BJ, Parsek MR, Ceri H, Turner RJ. Chromosomal antioxidant genes have metal ion-specific roles as determinants of bacterial metal tolerance. Environ Microbiol. 2009; 11: 2491-2509. 10.1111/j.1462-2920.2009.01973.x

Harrison KR, Kappell AD, McNamara PJ. Benzalkonium chloride alters phenotypic and genotypic antibiotic resistance profiles in a source water used for drinking water treatment. Environ Pollut. 2020; 257: 113472. 10.1016/j.envpol.2019.113472

Hartmann EM, Hickey R, Hsu T, Betancourt Román CM, Chen J, Schwager R, Kline J, Brown GZ, Halden RU, Huttenhower C, Green JL. Antimicrobial chemicals are associated with elevated antibiotic resistance genes in the indoor dust microbiome. Environ Sci Technol. 2016; 50: 9807-9815. 10.1021/acs.est.6b002625032049

Hasman H, Aarestrup FM. Relationship between copper, glycopeptide, and macrolide resistance among Enterococcus faecium strains isolated from pigs in Denmark between 1997 and 2003. Antimicrob Agents Chemother. 2005; 49: 2003-2006. 10.1128/AAC.49.1.454

Hasman $\mathrm{H}$, Aarestrup FM. tcrb, a gene conferring transferable copper resistance in Enterococcus faecium: occurrence, transferability, and linkage to macrolide and glycopeptide resistance. Antimicrob Agents Chemother. 2002; 46: 1410-1416. 10.1128/AAC.46.5.1410-1416.2002127162

Huang H, Zeng S, Dong X, Li D, Zhang Y, He M, Du P. Diverse and abundant antibiotics and antibiotic resistance genes in an urban water system. J Environ Manag. 2019; 231: 494-503. 10.1016/j.jenvman.2018.10.051

Jang HJ, Choi YJ, Ro HM, Ka JO. Effects of phosphate addition on biofilm bacterial communities and water quality in annular reactors equipped with stainless steel and ductile cast iron pipes. J Microbiol. 2012; 50: 17-28. 10.1007/s12275-012-1040-x

Ji P, Parks J, Edwards MA, Pruden A. Impact of water chemistry, pipe material and stagnation on the building plumbing microbiome. PLoS One. 2015; 10: 1-23. 10.1371/journal.pone.0141087

Ju F, Li B, Ma L, Wang Y, Huang D, Zhang T. Antibiotic resistance genes and human bacterial pathogens: cooccurrence, removal, and enrichment in municipal sewage sludge digesters. Water Res. 2016; 91: 1-10. 10.1016/j.watres.2015.11.071

Kang YC, Ooij WJ Van Lytle DA (2008) Characterization of copper corrosion products formed in drinking water by combining electrochemical and surface analyses. Corrosion 3346-3364

Kappell AD, De Nies MS, Ahuja NH, Ledeboer NA, Newton RJ, Hristova KR. Detection of multi-drug resistant Escherichia coli in the urban waterways of Milwaukee, WI. Front Microbiol. 2015; 6: 1-12. 10.3389/fmicb.2015.00336

Kappell AD, Harrison KR, McNamara PJ (2019) Effects of zinc orthophosphate on the antibiotic resistant bacterial community of a source water used for drinking water treatment. Environ Sci Water Res Technol. 10.1039/C9EW00374F

Kappell AD, Kimbell LK, Seib MD, Carey DE, Choi MJ, Kalayil T, Fujimoto M, Zitomer DH, McNamara PJ. Removal of antibiotic resistance genes in an anaerobic membrane bioreactor treating primary clarifier effluent at $20^{\circ} \mathrm{C}$. Environ Sci Water Res Technol. 2018; 4: 1783-1793. 10.1039/C8EW00270C

Kimbell LK, Kappell AD, McNamara PJ. Effect of pyrolysis on the removal of antibiotic resistance genes and class I integrons from municipal wastewater biosolids. Environ Sci Water Res Technol. 2018; 4: 1807-1818. 10.1039/C8EW00141C

Knapp CW, Callan AC, Aitken B, Shearn R, Koenders A, Hinwood A. Relationship between antibiotic resistance genes and metals in residential soil samples from Western Australia. Environ Sci Pollut Res. 2017; 24: 2484-2494. 10.1007/s11356-016-7997-y

Knapp CW, McCluskey SM, Singh BK, Campbell CD, Hudson G, Graham DW. Antibiotic resistance gene abundances correlate with metal and geochemical conditions in archived Scottish soils. PLoS One. 2011; 6: e27300. 10.1371/journal.pone.00273003212566 
Kogo A, Payne SJ, Andrews RC. Impact of corrosion control on biofilm development in simulated partial lead service line replacements. Environ Eng Sci. 2017; 34: 711-720. 10.1089/ees.2016.0507

Koike S, Krapac IG, Oliver HD, Yannarell AC, Chee-Sanford JC, Aminov RI, Mackie RI. Monitoring and source tracking of tetracycline resistance genes in lagoons and groundwater adjacent to swine production facilities over a 3-year period. Appl Environ Microbiol. 2007; 73: 4813-4823. 10.1128/AEM.00665071951052

Kusnetsov J, livanainen E, Elomaa N, Zacheus O, Martikainen PJ. Copper and silver ions more effective against Legionellae than against mycobacteria in a hospital warm water system. Water Res. 2001; 35: 42174225. 10.1016/S0043-1354(01)00124-5

Lane RW, Larson TE, Schilsky SW. Effect of pH on the silicate treatment of hot water in galvanized piping. J Am Water Works Assoc. 1977; 69: 457-461. 10.1002/j.1551-8833.1977.tb06789.x

LaPara TM, Burch TR, McNamara PJ, Tan DT, Yan M, Eichmiller JJ. Tertiary-treated municipal wastewater is a significant point source of antibiotic resistance genes into Duluth-Superior Harbor. Environ Sci Technol. 2011; 45: 9543-9549. 10.1021/es202775r

Lautenschlager K, Boon N, Wang Y, Egli T, Hammes F. Overnight stagnation of drinking water in household taps induces microbial growth and changes in community composition. Water Res. 2010; 44: 4868-4877. 10.1016/j.watres.2010.07.032

LeChevallier M, Besner M, Friedman M, Speight V (2011) Microbial quality control in distribution systems. In: Water Quality and Treatment: A Handbook of Drinking Water

Lehtola MJ, Laxander M, Miettinen IT, Hirvonen A, Vartiainen T, Martikainen PJ. The effects of changing water flow velocity on the formation of biofilms and water quality in pilot distribution system consisting of copper or polyethylene pipes. Water Res. 2006; 40: 2151-2160. 10.1016/j.watres.2006.04.010

Lehtola MJ, Miettinen IT, Lampola T, Hirvonen A, Vartiainen T, Martikainen PJ. Pipeline materials modify the effectiveness of disinfectants in drinking water distribution systems. Water Res. 2005; 39: 1962-1971. 10.1016/j.watres.2005.03.009

Lehtola MJ, Miettinen IT, Martikainen PJ. Biofilm formation in drinking water affected by low concentrations of phosphorus. Can J Microbiol. 2002; 48: 494-499. 10.1139/w02-048

Lemire JA, Harrison JJ, Turner RJ. Antimicrobial activity of metals: mechanisms, molecular targets and applications. Nat Rev Microbiol. 2013; 11: 371-384. 10.1038/nrmicro3028

Levy SB, Fitzgerald GB, Macone AB. Spread of antibiotic-resistant plasmids from chicken to chicken and from chicken to man. Nature. 1976; 260: 40-42. 10.1038/260040a0

Li X, Wang H, Hu C, Yang M, Hu H, Niu J. Characteristics of biofilms and iron corrosion scales with ground and surface waters in drinking water distribution systems. Corros Sci. 2015; 90: 331-339. 10.1016/j.corsci.2014.10.028

Lin W, Yu Z, Zhang H, Thompson IP. Diversity and dynamics of microbial communities at each step of treatment plant for potable water generation. Water Res. 2014; 52: 218-230. 10.1016/j.watres.2013.10.071

Ling F, Whitaker R, LeChevallier MW, Liu WT. Drinking water microbiome assembly induced by water stagnation. ISME J. 2018; 12: 1520-1531. 10.1038/s41396-018-0101-55955952

Lintereur PA, Duranceau SJ, Taylor JS, Stone ED. Sodium silicate impacts on lead release in a blended potable water distribution system. Desalin Water Treat. 2010; 16: 427-438. 10.5004/dwt.2010.1477

Liu G, Bakker GL, Li S, Vreeburg JHG, Verberk JQJC, Medema GJ, Liu WT, Van Dijk JC. Pyrosequencing reveals bacterial communities in unchlorinated drinking water distribution system: an integral study of bulk water, suspended solids, loose deposits, and pipe wall biofilm. Environ Sci Technol. 2014; 48: 5467-5476. 10.1021/es5009467

Liu S, Gunawan C, Barraud N, Rice SA, Harry EJ, Amal R. Understanding, monitoring, and controlling biofilm growth in drinking water distribution systems. Environ Sci Technol. 2016; 50: 8954-8976. 10.1021/acs.est.6b00835

Liu Z, Stout JE, Tedesco L, Boldin M, Hwang C, Diven WF, Yu VL. Controlled evaluation of copper-silver ionization in eradicating Legionella pneumophila from a hospital water distribution system. J Infect Dis. 1994; 169 : 919-922. 10.1093/infdis/169.4.919 
Lytle DA, Nadagouda MN. A comprehensive investigation of copper pitting corrosion in a drinking water distribution system. Corros Sci. 2010; 52: 1927-1938. 10.1016/j.corsci.2010.02.013

Lytle DA, Schock MR. Formation of Pb (IV) oxides in chlorinated water. J Am Water Works Assoc. 2005; 97: 102114. $10.2307 / 41313634$

Lytle DA, Sorg TJ, Frietch C. Accumulation of arsenic in drinking water distribution systems. Environ Sci Technol. 2004; 38: 5365-5372. 10.1021/es049850v

Ma L, Li AD, Le Yin X, Zhang T. The prevalence of integrons as the carrier of antibiotic resistance genes in natural and man-made environments. Environ Sci Technol. 2017; 51: 5721-5728. 10.1021/acs.est.6b05887

Ma L, Li B, Zhang T. New insights into antibiotic resistome in drinking water and management perspectives: a metagenomic based study of small-sized microbes. Water Res. 2019; 152: 191-201. 10.1016/j.watres.2018.12.069

Ma X, Vikram A, Casson L, Bibby K. Centralized drinking water treatment operations shape bacterial and fungal community structure. Environ Sci Technol. 2017; 51: 7648-7657. 10.1021/acs.est.7b00768

Ma Y, Wilson CA, Novak JT, Riffat R, Aynur S, Murthy S, Pruden A. Effect of various sludge digestion conditions on sulfonamide, macrolide, and tetracycline resistance genes and class I integrons. Environ Sci Technol. 2011; 45: 7855-7861. 10.1021/es200827t

Mackie RI, Koike S, Krapac I, Chee-Sanford J, Maxwell S, Aminov RI. Tetracycline residues and tetracycline resistance genes in groundwater impacted by swine production facilities. Anim Biotechnol. 2006; 17: 157-176. 10.1080/10495390600956953

Manuel CM, Nunes OC, Melo LF. Dynamics of drinking water biofilm in flow/non-flow conditions. Water Res. 2007; 41: 551-562. 10.1016/j.watres.2006.11.007

Mao D, Yu S, Rysz M, Luo Y, Yang F, Li F, Hou J, Mu Q, Alvarez PJJ. Prevalence and proliferation of antibiotic resistance genes in two municipal wastewater treatment plants. Water Res. 2015; 85: 458-466. 10.1016/j.watres.2015.09.010

Martinez JL, Sánchez MB, Martínez-Solano L, Hernandez A, Garmendia L, Fajardo A, Alvarez-Ortega C. Functional role of bacterial multidrug efflux pumps in microbial natural ecosystems. FEMS Microbiol Rev. 2009; 33: 430-449. 10.1111/j.1574-6976.2008.00157.x

McNeill L, Edwards M. Phosphate inhibitor use at US utilities. J Am Water Works Assoc. 2002; 94: 57-63. 10.1002/j.1551-8833.2002.tb09506.x

McNeill LS, Edwards M. Iron pipe corrosion in distribution systems. J Am Water Works Assoc. 2001; 93: 88-100. 10.1002/j.1551-8833.2001.tb09246.x

McNeill LS, Edwards M. Importance of $\mathrm{Pb}$ and Cu particulate species for corrosion control. J Environ Eng. 2004; 130: 136-144. 10.1061/(asce)0733-9372(2004)130:2(136)

Morvay AA, Decun M, Scurtu M, Sala C, Morar A, Sarandan M. Biofilm formation on materials commonly used in household drinking water systems. Water Sci Technol Water Supply. 2011; 11: 252-257.

10.2166/ws.2011.053

Munir M, Xagoraraki I. Levels of antibiotic resistance genes in manure, biosolids, and fertilized soil. J Environ Qual. 2011; 40: 248. 10.2134/jeq2010.0209

Neu L, Proctor CR, Walser J, Hammes F. Small-scale heterogeneity in drinking water biofilms. Front Microbiol. 2019; 10: 1-14. 10.3389/fmicb.2019.02446

Nguyen C, Elfland C, Edwards M. Impact of advanced water conservation features and new copper pipe on rapid chloramine decay and microbial regrowth. Water Res. 2012; 46: 611-621. 10.1016/j.watres.2011.11.006

Niquette P, Servais P, Savoir R. Impacts of pipe materials on densities of fixed bacterial biomass in a drinking water distribution system. Water Res. 2000; 34: 1952-1956. 10.1016/S0043-1354(99)00307-3

Noel JD, Wang Y, Giammar DE. Effect of water chemistry on the dissolution rate ofthe lead corrosion product hydrocerussite. Water Res. 2014; 54: 237-246. 10.1016/j.watres.2014.02.004

Oh S, Hammes F, Liu WT. Metagenomic characterization of biofilter microbial communities in a full-scale drinking water treatment plant. Water Res. 2018; 128: 278-285. 10.1016/j.watres.2017.10.054 
Outten FW, Huffman DL, Hale JA, O'Halloran TV. The independent cue and cus systems confer copper tolerance during aerobic and anaerobic growth in Escherichia coli. J Biol Chem. 2001; 276: 30670-30677. 10.1074/jbc.M104122200

Pal C, Asiani K, Arya S, Rensing C, Stekel DJ, Larsson DGJ, Hobman JL. Metal resistance and its association with antibiotic resistance. Adv Microb Physiol. 2017; 70: 261-313. 10.1016/bs.ampbs.2017.02.001

Pal C, Bengtsson-Palme J, Kristiansson E, Larsson DGJ. Co-occurrence of resistance genes to antibiotics, biocides and metals reveals novel insights into their co-selection potential. BMC Genomics. 2015; 16: 1-14. 10.1186/s12864-015-2153-5

Pal C, Bengtsson-Palme J, Rensing C, Kristiansson E, Larsson DGJ. BacMet: antibacterial biocide and metal resistance genes database. Nucleic Acids Res. 2014; 42: 737-743. 10.1093/nar/gkt1252

Pang H, Gao F, Lu Q (2009) Morphology effect on antibacterial activity of cuprous oxide. Chem Commun:10761078. 10.1039/b816670f

Payne SJ, Piorkowski GS, Hansen LT, Gagnon GA. Impact of zinc orthophosphate on simulated drinking water biofilms influenced by lead and copper. J Environ Eng. 2016; 142: 1136-1144. 10.1061/(ASCE)EE

Peltier E, Vincent J, Finn C, Graham DW. Zinc-induced antibiotic resistance in activated sludge bioreactors. Water Res. 2010; 44: 3829-3836. 10.1016/j.watres.2010.04.041

Peng CY, Hill AS, Friedman MJ, Valentine RL, Larson GS, Romero AMY, Reiber SH, Korshin GV. Occurrence of trace inorganic contaminants in drinking water distribution systems. J Am Water Works Assoc. 2012; 104: 53-54. 10.5942/jawwa.2012.104.0042

Peng CY, Korshin GV. Speciation of trace inorganic contaminants in corrosion scales and deposits formed in drinking water distribution systems. Water Res. 2011; 45: 5553-5563. 10.1016/j.watres.2011.08.017

Peng CY, Korshin GV, Valentine RL, Hill AS, Friedman MJ, Reiber SH. Characterization of elemental and structural composition of corrosion scales and deposits formed in drinking water distribution systems. Water Res. 2010; 44: 4570-4580. 10.1016/j.watres.2010.05.043

Pinto A, Schroeder J, Lunn M, Sloan W, Raskin L. Spatial-temporal survey and occupancy-abundance modeling to predict bacterial community dynamics in the drinking water microbiome. MBio. 2014; 5: 1-13. 10.1128/mBio.01135-14.Editor

Pinto AJ, Xi C, Raskin L (2012) Bacterial community structure in the drinking water microbiome is governed by filtration processes. Environ Sci Technol. 10.1021/es302042t

Poole K. At the nexus of antibiotics and metals: the impact of $\mathrm{Cu}$ and $\mathrm{Zn}$ on antibiotic activity and resistance. Trends Microbiol. 2017; 25: 820-832. 10.1016/j.tim.2017.04.010

Potgieter S, Pinto A, Sigudu M, du Preez H, Ncube E, Venter S. Long-term spatial and temporal microbial community dynamics in a large-scale drinking water distribution system with multiple disinfectant regimes. Water Res. 2018; 139: 406-419. 10.1016/j.watres.2018.03.077

Prest El, Weissbrodt DG, Hammes F, Van Loosdrecht MCM, Vrouwenvelder JS. Long-term bacterial dynamics in a full-scale drinking water distribution system. PLoS One. 2016; 11: 1-20. 10.1371/journal.pone.0164445

Proctor CR, Dai D, Edwards MA, Pruden A. Interactive effects of temperature, organic carbon, and pipe material on microbiota composition and Legionella pneumophila in hot water plumbing systems. Microbiome. 2017; 5: 130. 10.1186/s40168-017-0348-55628487

Proctor CR, Hammes F. Drinking water microbiology-from measurement to management. Curr Opin Biotechnol. 2015; 33: 87-94. 10.1016/j.copbio.2014.12.014

Pruden A, Alcalde RE, Alvarez PJJ, Ashbolt N, Bischel H, Capiro NL, Crossette E, Frigon D, Grimes K, Haas CN, Ikuma K, Kappell A, LaPara T, Kimbell L, Li M, Li X, McNamara P, Seo Y, Sobsey MD, Sozzi E, NavabDaneshmand T, Raskin L, Riquelme MV, Vikesland P, Wigginton K, Zhou Z (2018) An environmental science and engineering framework for combating antimicrobial resistance. Environ Eng Sci 35:ees.2017.0520. 10.1089/ees.2017.0520

Pruden A, Arabi M, Storteboom HN. Correlation between upstream human activities and riverine antibiotic resistance genes. Environ Sci Technol. 2012; 46: 11541-11549. 10.1021/es302657r

Pruden A, Pei R, Storteboom H, Carlson KH. Antibiotic resistance genes as emerging contaminants: studies in northern Colorado. Environ Sci Technol. 2006; 40: 7445-7450. 10.1021/es060413। 
Rao NN, Kornberg A. Inorganic polyphosphate supports resistance and survival of stationary-phase Escherichia coli. J Bacteriol. 1996; 178: 1394-1400. 10.1128/jb.178.5.1394-1400.1996177814

Rensing C, Grass G. Escherichia coli mechanisms of copper homeostasis in a changing environment. FEMS Microbiol Rev. 2003; 27: 197-213. 10.1016/S0168-6445(03)00049-4

Rhoads WJ, Pruden A, Edwards MA. Interactive effects of corrosion, copper, and chloramines on Legionella and Mycobacteria in hot water plumbing. Environ Sci Technol. 2017; 51: 7065-7075. 10.1021/acs.est.6b05616

Rice EW, Wang P, Smith AL, Stadler LB (2020) Determining hosts of antibiotic resistance genes: a review of methodological advances. Environ Sci Technol Lett. 10.1021/acs.estlett.0c00202

Rocha J, Fernandes T, Riquelme MV, Zhu N, Pruden A, Manaia CM. Comparison of culture-and quantitative PCRbased indicators of antibiotic resistance in wastewater, recycled water, and tap water. Int J Environ Res Public Health. 2019; 16: 4217. 10.3390/ijerph162142176862664

Rompré A, Prévost M, Coallier J, Brisebois $\mathrm{P}$, Lavoie J. Impacts of implementing a corrosion control strategy on biofilm growth. Water Sci Technol. 2000; 41: 287-294. 10.2166/wst.2000.0457

Rożej A, Cydzik-Kwiatkowska A, Kowalska B, Kowalski D. Structure and microbial diversity of biofilms on different pipe materials of a model drinking water distribution systems. World J Microbiol Biotechnol. 2015; 31: 37-47. 10.1007/s11274-014-1761-6

Sakcham B, Kumar A, Cao B. Extracellular DNA in monochloraminated drinking water and its influence on DNAbased profiling of microbial community. Environ Sci Technol Lett. 2019; 6: 306-312. 10.1021/acs.estlett.9b00185

Sanganyado E, Gwenzi W. Antibiotic resistance in drinking water systems: occurrence, removal, and human health risks. Sci Total Environ. 2019; 669: 785-797. 10.1016/j.scitotenv.2019.03.162

Sarin P, Snoeyink VL, Bebee J, Jim KK, Beckett MA, Kriven WM, Clement JA. Iron release from corroded iron pipes in drinking water distribution systems: effect of dissolved oxygen. Water Res. 2004; 38: 1259-1269. 10.1016/j.watres.2003.11.022

Sarin P, Snoeyink VL, Bebee J, Kriven WM, Clement JA. Physico-chemical characteristics of corrosion scales in old iron pipes. Water Res. 2001; 35: 2961-2969. 10.1016/S0043-1354(00)00591-1

Schock MR, Hyland RN, Welch MM. Occurrence of contaminant accumulation in lead pipe scales from domestic drinking-water distribution systems. Environ Sci Technol. 2008; 42: 4285-4291. 10.1021/es702488v

Schock MR, Lytle DA, Sandvig AM, Clement J, Harmon SM. Replacing polyphosphate with silicate to solve lead, copper, and source water iron problems. J Am Water Works Assoc. 2005; 97: 84-93. 10.1002/j.15518833.2005.tb07521.x

Schock MR, Scheckel KG, Desantis MK, Gerke T (2005b) Mode of occurrence, treatment, and monitoring significance of tetravalent lead. 2005 Water Qual Technol Conf Proceedings, WQTC 2005

Seiler C, Berendonk TU. Heavy metal driven co-selection of antibiotic resistance in soil and water bodies impacted by agriculture and aquaculture. Front Microbiol. 2012; 3: 399. 10.3389/fmicb.2012.003993522115

Sharma VK, Johnson N, Cizmas L, McDonald TJ, Kim H. A review of the influence of treatment strategies on antibiotic resistant bacteria and antibiotic resistance genes. Chemosphere. 2016; 150: 702-714. 10.1016/j.chemosphere.2015.12.084

Shen Y, Huang C, Lin J, Wu W, Ashbolt NJ, Liu WT, Nguyen TH. Effect of disinfectant exposure on Legionella pneumophila associated with simulated drinking water biofilms: release, inactivation, and infectivity. Environ Sci Technol. 2017; 51: 2087-2095. 10.1021/acs.est.6b04754

Shen Y, Huang PC, Huang C, Sun P, Monroy GL, Wu W, Lin J, Espinosa-Marzal RM, Boppart SA, Liu WT, Nguyen TH. Effect of divalent ions and a polyphosphate on composition, structure, and stiffness of simulated drinking water biofilms. Npj Biofilms Microbiomes. 2018; 4: 1-9. 10.1038/s41522-018-0058-1

Song J, Rensing C, Holm PE, Virta M, Brandt KK. Comparison of metals and tetracycline as selective agents for development of tetracycline resistant bacterial communities in agricultural soil. Environ Sci Technol. 2017; 51: 3040-3047. 10.1021/acs.est.6b05342 
Stepanauskas R, Glenn TC, Jagoe CH, Tuckfield RC, Lindell AH, McArthur JV. Elevated microbial tolerance to metals and antibiotics in metal-contaminated industrial environments. Environ Sci Technol. 2005; 39: 3671-3678. 10.1021/es048468f

Su HC, Liu YS, Pan CG, Chen J, He LY, Ying GG. Persistence of antibiotic resistance genes and bacterial community changes in drinking water treatment system: from drinking water source to tap water. Sci Total Environ. 2018; 616-617: 453-461. 10.1016/j.scitotenv.2017.10.318

Sun H, Shi B, Bai Y, Wang D. Bacterial community of biofilms developed under different water supply conditions in a distribution system. Sci Total Environ. 2014; 472: 99-107. 10.1016/j.scitotenv.2013.11.017

Sun H, Shi B, Lytle DA, Bai Y, Wang D. Formation and release behavior of iron corrosion products under the influence of bacterial communities in a simulated water distribution system. Environ Sci Process Impacts. 2014; 16: 576-585. 10.1039/c3em00544e

Sun $\mathrm{H}$, Shi B, Yang F, Wang D. Effects of sulfate on heavy metal release from iron corrosion scales in drinking water distribution system. Water Res. 2017; 114: 69-77. 10.1016/j.watres.2017.02.021

Szekeres E, Chiriac CM, Baricz A, Szőke-Nagy T, Lung I, Soran ML, Rudi K, Dragos N, Coman C. Investigating antibiotics, antibiotic resistance genes, and microbial contaminants in groundwater in relation to the proximity of urban areas. Environ Pollut. 2018; 236: 734-744. 10.1016/j.envpol.2018.01.107

Van Der Kooij D, Veenendaal HR, Scheffer WJH. Biofilm formation and multiplication of Legionella in a model warm water system with pipes of copper, stainless steel and cross-linked polyethylene. Water Res. 2005; 39: 2789-2798. 10.1016/j.watres.2005.04.075

Van Hoek AHAM, Mevius D, Guerra B, Mullany P, Roberts AP, Aarts HJM. Acquired antibiotic resistance genes: An overview. Front Microbiol. 2011; 2: 2033202223

Vikesland PJ, Pruden A, Alvarez PJJ, Aga D, Bürgmann H, Li XD, Manaia CM, Nambi I, Wigginton K, Zhang T, Zhu YG. Toward a comprehensive strategy to mitigate dissemination of environmental sources of antibiotic resistance. Environ Sci Technol. 2017; 51: 13061-13069. 10.1021/acs.est.7b03623

Volk C, Dundore E, Schiermann J, Lechevallier M. Practical evaluation of iron corrosion control in a drinking water distribution system. Water Res. 2000; 34: 1967-1974. 10.1016/S0043-1354(99)00342-5

Waak MB, Hozalski RM, Hallé C, Lapara TM. Comparison of the microbiomes of two drinking water distribution systems - with and without residual chloramine disinfection. Microbiome. 2019; 7: 1-14. 10.1186/s40168-019-0707-5

Wang H, Masters S, Edwards MA, Falkinham JO, Pruden A. Effect of disinfectant, water age, and pipe materials on bacterial and eukaryotic community structure in drinking water biofilm. Environ Sci Technol. 2014; 48: 1426-1435. 10.1021/es402636u

Wang H, Masters S, Hong Y, Stallings J, Falkinham JO, Edwards MA, Pruden A. Effect of disinfectant, water age, and pipe material on occurrence and persistence of Legionella, mycobacteria, Pseudomonas aeruginosa, and two amoebas. Environ Sci Technol. 2012; 46: 11566-11574. 10.1021/es303212a

Waseem H, Jameel S, Ali J, Ur Rehman HS, Tauseef I, Farooq U, Jamal A, Ali MI. Contributions and challenges of high throughput qPCR for determining antimicrobial resistance in the environment: a critical review. Molecules. 2019; 24: 163. 10.3390/molecules240101636337382

WHO. Antimicrobial resistance. Global Report on Surveillance. Bull World Health Organ. 2014; 61: 383-394. 10.1007/s13312-014-0374-3

Wingender J, Flemming HC. Biofilms in drinking water and their role as reservoir for pathogens. Int J Hyg Environ Health. 2011; 214: 417-423. 10.1016/j.ijheh.2011.05.009

Wright MS, Peltier GL, Stepanauskas R, McArthur JV. Bacterial tolerances to metals and antibiotics in metalcontaminated and reference streams. FEMS Microbiol Ecol. 2006; 58: 293-302. 10.1111/j.15746941.2006.00154.x

Xi C, Zhang Y, Marrs CF, Ye W, Simon C, Foxman B, Nriagu J. Prevalence of antibiotic resistance in drinking water treatment and distribution systems. Appl Environ Microbiol. 2009; 75: 5714-5718. 10.1128/AEM.00382092737933 
Xiao W, Hong S, Tang Z, Seal S, Taylor JS. Effects of blending on surface characteristics of copper corrosion products in drinking water distribution systems. Corros Sci. 2007; 49: 449-468. 10.1016/j.corsci.2006.04.018

Xie Y, Giammar DE. Effects of flow and water chemistry on lead release rates from pipe scales. Water Res. 2011; 45: 6525-6534. 10.1016/j.watres.2011.09.050

Xie Y, Wang Y, Singhal V, Giammar DE. Effects of $\mathrm{pH}$ and carbonate concentration on dissolution rates of the lead corrosion product PbO2. Environ Sci Technol. 2010; 44: 1093-1099. 10.1021/es9026198

Xu L, Ouyang W, Qian Y, Su C, Su J, Chen H. High-throughput profiling of antibiotic resistance genes in drinking water treatment plants and distribution systems. Environ Pollut. 2016; 213: 119-126. 10.1016/j.envpol.2016.02.013

Yang F, Shi B, Gu J, Wang D, Yang M. Morphological and physicochemical characteristics of iron corrosion scales formed under different water source histories in a drinking water distribution system. Water Res. 2012; 46: 5423-5433. 10.1016/j.watres.2012.07.031

Yang Y, Liu G, Song W, Ye C, Lin H, Li Z, Liu W. Plastics in the marine environment are reservoirs for antibiotic and metal resistance genes. Environ Int. 2019; 123: 79-86. 10.1016/j.envint.2018.11.061

Zhang J, Li W, Chen J, Wang F, Qi W, Li Y. Impact of disinfectant on bacterial antibiotic resistance transfer between biofilm and tap water in a simulated distribution network. Environ Pollut. 2019; 246: 131-140. 10.1016/j.envpol.2018.11.077

Zhang K, Xin R, Zhao Z, Ma Y, Zhang Y, Niu Z. Antibiotic resistance genes in drinking water of China: occurrence, distribution and influencing factors. Ecotoxicol Environ Saf. 2020; 188: 109837. 10.1016/j.ecoenv.2019.109837

Zhang M, Chen L, Ye C, Yu X. Co-selection of antibiotic resistance via copper shock loading on bacteria from a drinking water bio-filter. Environ Pollut. 2018; 233: 132-141. 10.1016/j.envpol.2017.09.084

Zhang S, Wang Y, Song H, Lu J, Yuan Z, Guo J. Copper nanoparticles and copper ions promote horizontal transfer of plasmid-mediated multi-antibiotic resistance genes across bacterial genera. Environ Int. 2019; 129: 478-487. 10.1016/j.envint.2019.05.054

Zhang Y, Griffin A, Edwards M. Nitrification in premise plumbing: role of phosphate, $\mathrm{pH}$ and pipe corrosion. Environ Sci Technol. 2008; 42: 4280-4284. 10.1021/es702483d

Zhang Y, Gu AZ, Cen T, Li X, He M, Li D, Chen J. Sub-inhibitory concentrations of heavy metals facilitate the horizontal transfer of plasmid-mediated antibiotic resistance genes in water environment. Environ Pollut. 2018; 237: 74-82. 10.1016/j.envpol.2018.01.032

Zhang Y, Gu AZ, He M, Li D, Chen J. Subinhibitory concentrations of disinfectants promote the horizontal transfer of multidrug resistance genes within and across genera. Environ Sci Technol. 2017; 51; 1: 570-580. 10.1021/acs.est.6b03132

Zhang Y, Gu AZ, Xie S, Li X, Cen T, Li D, Chen J. Nano-metal oxides induce antimicrobial resistance via radicalmediated mutagenesis. Environ Int. 2018; 121: 1162-1171. 10.1016/j.envint.2018.10.030

Zhang Y, Love N, Edwards M. Nitrification in drinking water systems. Crit Rev Environ Sci Technol. 2009; 39: 153208. 10.1080/10643380701631739

Zhou X, Shen Y, Fu X, Wu F. Application of sodium silicate enhances cucumber resistance to Fusarium wilt and alters soil microbial communities. Front Plant Sci. 2018; 9: 1-12. 10.3389/fpls.2018.00624

Zhu Y, Wang H, Li X, Hu C, Yang M, Qu J. Characterization of biofilm and corrosion of cast iron pipes in drinking water distribution system with UV/Cl2disinfection. Water Res. 2014; 60: 174-181. 10.1016/j.watres.2014.04.035

Zlatanović L, van der Hoek JP, Vreeburg JHG. An experimental study on the influence of water stagnation and temperature change on water quality in a full-scale domestic drinking water system. Water Res. 2017; 123: 761-772. 10.1016/j.watres.2017.07.019 
